\title{
The Effect of Problem Based Learning and Inquiry on Critical Thinking Ability (Experimental Study on Entrepreneurship Subject at FKIP, Universitas Kuningan)
}

\author{
Cucu Suhartini ${ }^{1}$, Rani Tania Pratiwi ${ }^{2}$, Iyan Setiawan ${ }^{3}$, Yeyen Suryani ${ }^{4}$ \\ Universitas Kuningan, Indonesia \\ \{cucu.suhartini@uniku.ac.id¹, rani.tania.pratiwi@uniku.ac.id², iyan.setiawan@uniku.ac.id², \\ yeyen.suryani@uniku.ac.id $\left.{ }^{4}\right\}$
}

\begin{abstract}
The problem behind this research is the low critical thinking skills of students. This is due to many factors, one of them is that the learning that is carried out tends to use conventional learning methods which are considered unable to develop students' thinking skills, especially critical thinking. The purpose of this study is to find out the ability to think critically after implementing Problem-Based Learning, Inquiry and Conventional learning models. The method used is a quasi-experimental research design with Counterbalance Design. Critical thinking test is the instrument utilized in this research. The research subjects consist of FKIP Universitas Kuningan students from Indonesian Education and Literature Department (PBSI), Economics Education Department, and Mathematics Education Department, where each class was given treatment using different methods. Based on the test results using the ANOVA test, the results obtained with a significant value $<0.050$, which means that the availability of students' critical thinking skills from each treatment conducted in each class using different methods and different subjects, so that the proposed hypothesis can be accepted. Judging from the results of the average value (mean) of students' critical thinking skills in each study program, it shows that the Problem Based Learning model is higher than the Inquiry and Conventional learning models. The conclusion of this study is that the Problem Based Learning model is more effective in improving students' critical thinking skills in entrepreneurship courses

Keywords: Critical Thinking Ability; Problem Based Learning; Inquiry and Conventional
\end{abstract}

\section{Introduction}

Education is the key to all progress and quality development, because with education humans can realize all their potential both as individuals and as citizens of society. The aspect of the learning process is one of the reasons for the need to improve the quality of education. The low quality of the teaching and learning process shows that the interaction between students and learning resources such as teachers and the environment, does not work effectively so that the learning outcomes achieved are not optimal. Students who learn are expected to experience changes both in the fields of knowledge, understanding, skills, values and attitudes. 
The development of the 21 st century requires students to have competencies, including having critical thinking and problem solving skills, communication and collaboration skills, creativity and innovation skills, information and communication technology literacy skills, contextual learning skills, and information and media literacy skills. As that 21 st century skills emphasize the ability to think critically4, solve problems, communicate and cooperate which are parts of HOTS (High Order Thinking Skills) or higher order thinking skills. Likewise, one of the challenges of globalization in the 21 st century demands that all people have characteristics, one of which has critical and systematic abilities.

The ability to think critically, which is included in the realm of higher order thinking skills, really needs to be possessed by students as a provision for facing various kinds of challenges in an increasingly complex globalization era. It is known that students' Critical Thinking Ability in the Entrepreneurship course in the Economic Education study program still shows the ability to think low, this is shown by many students who do not pay attention when the lecture process is taking place, still have difficulty in carrying out questions and expressing their opinions during discussions. This shows that the critical thinking skills of economic education students still need improvement. Especially in the course of entrepreneurship so that students can be inspired to do independence in entrepreneurship, students can change their dependence on others to become independent.

Problems related to students' critical thinking skills cause students to be hampered and find it difficult to face problems that require more complex thinking and problem solving8. This is one of the impacts if the learning process that has been happening until now continues to be applied without any variation and creativity from a lecturer to create and improve a more constructive learning process. Ideally, in the learning process in the classroom, the lecturer must be able to make variations in learning activities both in terms of models, methods or learning media that are interesting and fun. So that the role of educators is very important in helping students to improve their critical thinking skills.

Problem-Based Learning (PBL) is a learning model that can be applied to learning in the 2013 curriculum because it can encourage students to think critically, solve problem skills, connect knowledge about problems, and real-world issues. Inquiry is a learning model that is thought to help students empower their critical thinking skills. Guided Inquiry implementation, can be done by students based on the instructions of the lecturer. The instructions given are generally in the form of guiding questions. Learning implementation starts from a core question. From the answers stated, students conduct investigations to prove the opinions that have been expressed. That the cooperative learning model can improve students 'critical thinking skills. So it can be concluded that the Problem Base Learning (PBL) and Inquiry learning model are effective learning models in improving students' critical thinking skills.

Social phenomena that currently appear are shown by negative behaviors and symptoms that indicate the erosion of the character of a nation. This phenomenon can be seen in daily life at school and in the community that there are still many students who do deviant deeds. When viewed further, the degradation of the values and morals of Pancasila as the core of character formation has not only struck the younger generation, but has penetrated to community leaders, students, educators, political officials, even to the leaders of the nation and state.

\subsection{Research Questions}

1. Is there any differences in the improvement of students' critical thinking skills in the class using problem based learning model with the inquiry learning model? 
2. Is there any differences in the improvement of students' critical thinking skills in the class with a problem based learning model with conventional learning?

3. Is there any differences in the improvement of students' critical thinking skills in the class using the inquiry learning model with conventional learning?

\subsection{Research Questions}

The framework of thinking is basically the direction of the research line of thought in answering the formulated problem. Based on the theories that have been stated previously, a framework of thinking is made as follows:

a. The learning process that is widely used by teachers so far makes students tend to be passive. Students listen more to what the teaching staff says without knowing the purpose and meaning of the learning. These conventional learning activities are more dominated by teachers or are more teacher center in nature, and students are less involved in learning so that learning becomes less meaningful for students.

b. One of the efforts to provide opportunities for students to be more active in learning is to apply a learning model that provides wider space for students, namely the Inquiry and Problem-based learning models.

c. From research that has been carried out, problem based learning and inquiry learning models are effective in increasing critical thinking so that researchers are interested in comparing the effects of these models in learning, a frame of mind can be made which can be seen in Figure 1.

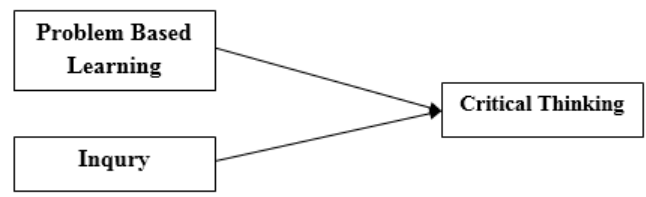

Fig 1. Framework of Thinking

\section{Method}

This study uses a qualitative method. Qualitative research includes the use of the subject being examined and a collection of various empirical data on case studies, personal experiences, introspection, life's journey, interviews, observational texts, historical, daily and problematic meanings and problems in one's life [9].

\subsection{Research Method}

In this study, the Quasi Experimental Design method was used, which is a type of experiment that uses all intact subjects (intake groups) to be given treatment for Quasi Experimental Design (quasi-experimental) used in this study is Counterbalanced Design. Each class gets a treatment (treatment) which is done online through google meet.

\subsection{Research Subject}

In this study, 62 students of FKIP University of Kuningan from the Indonesian Language and Literature Education Department (PBSI), Economic Education (PE) and Mathematics Education were 62 students from three classes in each of these study programs. During the COVID-19 pandemic, the implementation of experiments for this research was carried out online using google meet in each cycle. 
Table 1. Research Subject

\begin{tabular}{cccc}
\hline \multirow{2}{*}{ Department } & First Cycle & Second Cycle & Third Cycle \\
\cline { 2 - 4 } Indonesian Language & Problem Based & Inquiry & Conventional \\
and Literature Education & Learning (PBL) & & Problem Based \\
Economic Education & Inquiry & Conventional & Learning (PBL) \\
Mathematics Education & Conventional & Problem Based & Learning (PBL) \\
\end{tabular}

\subsection{Data Collection Technique}

The research method is the steps and procedures that will be carried out to collect data in order to solve problems or test hypotheses. In this study, the measuring instrument used to measure the level of critical thinking skills of students used a written test where the test was carried out for all three classes. During the COVID-19 pandemic, lectures were carried out online, and written tests to measure students' critical thinking skills were carried out online by filling in the bit.ly link.

\section{Result and Discussion}

The use of learning models is related to the learning material to be delivered. Learning materials have different levels of difficulty so that techniques, methods and strategies are needed that are relevant to the characteristics of the material. The use of relevant learning methods and models will certainly be directly proportional to learning outcomes. Of course, good learning outcomes are the contribution of the use of learning methods and models used in the learning process. Analysis of the effectiveness of increasing the use of models that have been carried out in lectures for three different classes in different study programs as learning subjects in this research, shows that the effectiveness of the application of the learning model carried out has a different effect on students' critical thinking abilities.

Studies I, II and III always show that the Problem Based Learning (PBL) model is more effective than the Inquiry and Conventional models. These results are based on testing the average value derived from the value of each student through the given pretest, posttest and gain. The following is an overview of the gain results from each treatment that has been carried out.

Table 2. Average Gain Score

\begin{tabular}{|c|c|c|c|c|c|c|}
\hline \multirow{2}{*}{ No } & \multirow{2}{*}{ Model } & \multicolumn{3}{|c|}{ Study } & \multirow{2}{*}{ Total } & \multirow{2}{*}{ Average } \\
\hline & & $\mathrm{I}$ & II & III & & \\
\hline 1. & PBL & 33 & 35,5 & 38,8 & 107,3 & 35,7 \\
\hline 2. & Inquiry & 24,4 & 25,3 & 27,1 & 76,8 & 25,6 \\
\hline 3. & Conventional & 17,1 & 15,6 & 20,9 & 53,6 & 17,8 \\
\hline
\end{tabular}

\subsection{Effectiveness of Using Problem Based Learning Compared to Inquiry}

Based on the results of the research and statistical testing that has been done, it shows a significant difference between the PBL and Inquiry models in increasing critical thinking skills, both in studies I, II and study III. This means that the PBL and Inquiry models affect the improvement of students' critical thinking skills. That the results of the study conducted by researchers Sunarti and Rosanti reported the results that students' critical thinking skills could 
be improved by a variety of learning models, especially PBL and Inquiry models. This can be seen from the results of the ANOVA analysis with the post hoc test that has been carried out showing a significance value $<0.05$ in each study. This means that significantly the PBL and Inquiry learning model can improve students' critical thinking skills.

Table 3. Post Hoc Test Results

\begin{tabular}{cc}
\hline Study & Post Hoc Test Results \\
\hline I & 0,030 \\
II & 0,040 \\
III & 0,041 \\
\hline
\end{tabular}

So thus there is an influence when using the PBL and Inquiry models to increase critical thinking skills. In addition, other research results indicate that there is an increase in students' critical thinking in the PBL and Inquiry models.

\subsection{The Effectiveness of Using Problem Based Learning Compared to Conventional}

Based on the results of research and statistical testing that has been carried out, it shows the differences between PBL and conventional models in improving critical thinking skills in studies I, II and study III. This means that the PBL model affects students' critical thinking skills. This can be seen from the results of the ANOVA analysis with the post hoc test that has been carried out showing a significance value $<0.05$ in each study. This means that the PBL learning model is significantly more effective in improving students' critical thinking skills.

Table 4. Post Hoc Test Results

\begin{tabular}{cc}
\hline Study & Post Hoc Test Results \\
\hline I & 0,005 \\
II & 0,049 \\
III & 0,046 \\
\hline
\end{tabular}

Thus there is an effect of the Problem Based Learning model to improve students' critical thinking skills compared to conventional learning. And that Problem Based Learning has an effect on increasing critical thinking skills.

\subsection{The Effectiveness of Using Inquiry compared to Conventional}

Based on the results of the research and statistical tests that have been carried out, significant results were obtained between the Inquiry and conventional models in improving critical thinking skills in studies I, II and study III. This means that the Inquiry model has an effect on improving students' thinking skills. This can be seen from the results of the ANOVA analysis with the post hoc test that has been carried out showing a significance value $<0.05$ in each study. This means that significantly the Inquiry learning model can improve critical thinking skills compared to conventional methods.

Table 5. Post Hoc Test Results

\begin{tabular}{cc}
\hline Study & Post Hoc Test Results \\
\hline I & 0,032 \\
II & 0,033 \\
III & 0,048 \\
\hline
\end{tabular}

So thus the Inquiry learning model has more influence on students 'critical thinking skills. Similarly, inquiry learning has a positive influence on students' critical thinking abilities.

\section{Conclusion}

Based on the results of research conducted, the Problem Based Learning (PBL) learning model is more effective in improving students' critical thinking skills compared to Inquiry and 
Conventional. Where when learning students are more enthusiastic in participating in learning activities, students can discuss actively in expressing their ideas and opinions, so that questioning activities develop more, this shows an increase in the quality of learning with the application of the Problem Based Learning model. Thus, the application of the Problem Based Learning model is better and can improve students' critical thinking skills.

\section{References}

[1] Purwanti, Endang. Asesmen Pembelajaran SD. Jakarta: Depdiknas, 2008

[2] Suryani, Yeyen, and Cucu Suhartini. "Penggunaan Model Problem Based Learning Pengaruhnya Terhadap Motivasi Belajar Dan Kemampuan Berfikir Kreatif (Studi Eksperimen Pada Mata Kuliah Pengantar Ilmu Ekonomi Tingkat II Program Studi Pendidikan Ekonomi FKIP Universitas Kuningan).” Equilibrium: Jurnal Penelitian Pendidikan dan Ekonomi 14, no. 02 (April 21, 2018): 88. https://doi.org/10.25134/equi.v15i01.1074.

[3] Badan Standar Nasional Pendidikan. Paradigma Pendidikan Nasional Di Abad-21. Jakarta: BSNP, 2010.

[4] Daniel P., Hallahan, Kauffman James M., and Pullen Paige C. Exceptional Learner An Introduction to Special Education. United States of America: PEARSON, 2009.

[5] Cogan, J.J, and R. Derricott. Citizenship for the 21st Century: An International Perspective on Education. London: Kogan Page, 1998.

[6] Khoer, Misbahul. "Pengaruh Efektivitas Penerapan Model Pembelajaran Kooperatif Tipe Numbered Head Together (Nht), Mind Mapping, Dan Talking Chips Terhadap Peningkatan Kemampuan Berpikir Kritis Siswa" 16, no. 1 (2019): 12.

[7] Suhartini, Cucu. "Pengaruh Pengetahuan Kewirausahaan Dan Efikasi Diri Terhadap Motivasi Berwirausaha Mahasiswa" 17, no. 02 (2020): 8

[8] Setiawan, Iyan. "Pengaruh Model Pembelajaran Kooperatif Tipe Jigsaw Terhadap Keterampilan Sosial Dan Kemampuan Berpikir Kritis Siswa" 16, no. 1 (2019): 12.

[9] Slameto. "Developing Critical Thinking Skills through School Teacher Training "Training and Development Personnel' Model and Their Determinants of Success." International Journal of Information and Education Technology 4, no. 2 (2014): 161-66. https://doi.org/10.7763/IJIET.2014.V4.390.

[10] Savich, Carl Kosta. "Improving Critical Thinking Skills in History.” Networks: An Online Journal for Teacher Research 11, no. 2 (December 20, 2009): 180-180. https://doi.org/10.4148/24706353.1106

[11] Sumiati, and Asra. Metode Pembelajaran. Bandung: Wacana Prima, 2008.

[12] Changwong, Ken, Aukkapong Sukkamart, and Boonchan Sisan. "Critical Thinking Skill Development: Analysis of a New Learning Management Model for Thai High Schools." Journal of International Studies 11, no. 2 (June 30, 2018): 37-48. https://doi.org/10.14254/2071$8330.2018 / 11-2 / 3$.

[13] Gunawan, A Harjono, H Sahidu, and Nisrina. "Improving Students' Creativity Using Cooperative Learning with Virtual Media on Static Fluida Concept.” Journal of Physics: Conference Series 1006 (April 2018): 012016. https://doi.org/10.1088/1742-6596/1006/1/012016.

[14] Mandusic, D., and L. Blaskovic. "The Impact of Collaborative Learning to Critically Thinking." Trakia Journal of Science 13, no. Suppl.1 (2015): 426-28. https://doi.org/10.15547/tjs.2015.s.01.073.

[15] Sunarti, Iin. "Penerapan Model Pembelajaran Problem Based Learning (PBL) Terhadap Kemampuan Berpikir Kritis Siswa” 16, no. 1 (2019): 11.

[16] Andrasmoro, Dony. "Pengaruh Model Inquiry Terhadap Berpikir Kritis Mahasiswa Geografi IkipPgri Pontianak" 3, no. 2 (2016): 11.

[17] Azizah, Linda Ilmi Rahmah, and Nurina Happy. "Efektivitas Model Pembelajaran Problem-Based Learning (PBL) dan Guided Inquiry terhadap Kemampuan Berpikir Kritis Matematis Siswa," n.d. 
[18] Apriana, Evi, and Anwar Anwar. "Penerapan Model Pembelajaran Problem Based Learning Dan Inkuiri Untuk Meningkatkan Kemampuan Berpikir Kritis Mahasiswa Pada Konsep Dampak Pencemaran Lingkungan Terhadap Kesehatan.” BIOTIK: Jurnal Ilmiah Biologi Teknologi dan Kependidikan 2, no. 2 (January 31, 2017): 132. https://doi.org/10.22373/biotik.v2i2.247.

[19] Steven, Dino, La Ndia La Ndia, and La Arapu La Arapu. "Pengaruh Model Problem Based Learning Terhadap Kemampuan Berpikir Kritis Matematis Peserta Didik Kelas VIII SMP Negeri 2 Kendari." Jurnal Penelitian Pendidikan Matematika 7, no. 3 (October 31, 2019): 15. https://doi.org/10.36709/jppm.v7i3.9278.

[20] Thahara, Intan Putri, Hari Mulyadi, and Dian H Utama. "Efektivitas Model Problem Based Learning Dalam Meningkatkan Kemampuan Berpikir Kritis Peserta Didik Pada Kelas Bisnis Dan Kewirausahaan" 1, no. 2 (2016): 5.

[21] Masitoh, Ikhlasun Dwi, and Joko Ariyanto. "Pengaruh Model Pembelajaran Inkuiri Terbimbing terhadap Kemampuan Berpikir Kritis Siswa Kelas X MIA pada Materi Pencemaran Lingkungan di Surakarta," 2017, 9.

[22] Ariyati, Eka. "Pengaruh Pembelajaran Inkuiri Terhadap Kemampuan Berpikir Kritis Mahasiswa," $2015,9$. 